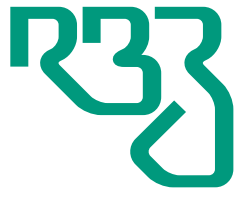

Revista Brasileira de Zootecnia

Brazilian Journal of Animal Science ISSN 1806-9290 www.rbz.org.br

\section{Effects of Curcuma longa rhizome on growth, skin pigmentation, and stress tolerance after transport of Trichogaster labiosa}

\author{
Lidiane da Silva Nascimento ${ }^{1}$ iD , Sendy Moreira Reis ${ }^{1}$ iD, Pollyanna de \\ Moraes França Ferreira $^{1}$ (iD), Márcio Yoshiyuki Kanashiro ${ }^{1}$ (iD), Ana Lúcia \\ Salaro $^{1}$ iD , Jener Alexandre Sampaio Zuanon ${ }^{1 *}$ iD \\ ${ }^{1}$ Universidade Federal de Viçosa, Departamento de Biologia Animal, Viçosa, MG, Brasil.
}

\begin{abstract}
We aimed to evaluate the effects of Curcuma longa as growth promoter, skin pigmentation enhancer, and stress reducer in diets of Trichogaster labiosa after transport. We used five diets containing $0.0,1.0,5.0,10.0$, and $25.0 \mathrm{~g} \mathrm{~kg}^{-1}$ of turmeric rhizome powder. We observed quadratic effects of turmeric supplementation for feed intake, weight gain, final length, and specific growth rate. The estimated amount of turmeric that decreased these variables ranged from 15.53 to $16.39 \mathrm{~g} \mathrm{~kg}^{-1}$. Quadratic effects of supplementation of turmeric for cyan and black dorsal skin coloring indices were observed, with estimated values that increased these variables equal to 15.03 and $17.44 \mathrm{~g} \mathrm{~kg}^{-1}$, respectively. After fish transport, quadratic effects of turmeric were observed for the cyan and black dorsal skin depigmentation indices, with estimated values that increased these variables equal to 13.29 and $17.04 \mathrm{~g} \mathrm{~kg}^{-1}$, respectively. These results demonstrate that supplementation with turmeric at levels up to $17 \mathrm{~g} \mathrm{~kg}^{-1}$ causes further reduction in skin color due to the stress of transport. Thus, Curcuma longa acts neither as a growth promoter nor as a stress reducer for Trichogaster labiosa. Curcuma longa does not improve the orange pattern of skin pigmentation in the strain of T. labiosa orange thick-lipped gourami.
\end{abstract}

\title{
Introduction
}

In ornamental fish trade, animals experience procedures, such as capture, size sorting, and fasting before transport, which can trigger stress responses and cause a decrease in skin color and consequent reduction of its market value (Dharmaraj and Dhevendaran, 2011). In fish that remain in ponds, frequent captures and size-sorting management can cause chronic stress responses once fishing is partial. Under these conditions, the fish have reduced growth (Barton, 2002), decreased activity of their immune systems (Wendelaar Bonga, 1997), and lower disease resistance (Lima et al., 2006).

To reduce losses associated with stress, it is common to use additives in the water, such as sodium chloride (Gomes et al., 2003; Brandão et al., 2008) and anesthetics (Becker et al., 2016; Moreira et al., 2015). However, the use of additives in fish diets in preparation for transport has not been well studied. The use of these additives can help increase stress resistance (Aly and Mohamed, 2010; Zeppenfeld et al., 2014) and improve the activity of the immune system (Rao et al., 2006; Sahu et al., 2008).

Among the plant extracts, turmeric (Curcuma longa) rhizome has potential as a dietary additive for reducing stress responses (Xia et al., 2007) and improving fish growth and health due to its antimicrobial (Gaikwad et al., 2014), antioxidant (Ramadan et al., 2011), anti-inflammatory (Ramadan et al., 2011; 
Nonose et al., 2014), immunostimulatory properties (Srivastava et al., 2011), and its stimulating effect on digestive enzymes secretion (Pransin, 2006). Turmeric also has potential for skin pigmentation in ornamental fish due to its rich yellow-orange pigments, such as curcumin, demethoxycurcumin, and bisdemethoxycurcumin (Naghetini, 2006).

The Trichogaster genus is among the most popular ornamental fish species in the world (Rüber et al., 2006). Trichogaster labiosa, formerly classified as Colisa labiosa, stands out due to its docility and peaceful coexistence with other species. The strain known as "orange thick-lipped gourami" is widely marketed due to its orange coloration. This strain resulted from genetic improvements that replaced the barred blue and orange patterns to a uniformly orange pattern.

In this study, we aimed to evaluate the potential of $C$. longa as growth promoter, skin pigmentation enhancer, and stress reducer for T. labiosa after transport.

\section{Material and Methods}

The experiment was carried out in Viçosa, MG, Brazil (2045'14" S, 42 $\left.52^{\prime} 55^{\prime \prime} \mathrm{W}\right)$ and was approved by the Ethics Committee on Animal Use (CEUAP - case no. 05/2013).

The experiment consisted of a randomized block design with five treatments and two replicates within each block, totaling 20 experimental units. Block 1 (B1) consisted of fish with an average weight of $0.61 \pm 0.02 \mathrm{~g}$, and block 2 (B2) contained fish with an average weight of $0.77 \pm 0.02 \mathrm{~g}$. The treatments consisted of five practical diets containing $0.0,1.0,5.0,10.0$, and $25.0 \mathrm{~g} \mathrm{~kg}^{-1}$ of turmeric rhizome (C. longa) powder (Table 1). Each aquarium was considered a replicate.

Table 1 - Formulations and calculated chemical compositions of experimental diets

\begin{tabular}{|c|c|c|c|c|c|}
\hline & \multicolumn{5}{|c|}{ Level of turmeric in the diets $\left(\mathrm{g} \mathrm{kg}^{-1}\right)$} \\
\hline & 0.0 & 1.0 & 5.0 & 10.0 & 25.0 \\
\hline Soybean meal & 445.00 & 445.00 & 445.00 & 445.00 & 447.00 \\
\hline Fish meal & 200.00 & 200.00 & 200.00 & 200.00 & 200.00 \\
\hline Turmeric & 00.00 & 1.00 & 5.00 & 10.00 & 25.00 \\
\hline Wheat bran & 100.00 & 100.00 & 100.00 & 100.00 & 100.00 \\
\hline Sorghum & 178.30 & 177.30 & 173.30 & 168.30 & 151.30 \\
\hline DL-methionine & 2.00 & 2.00 & 2.00 & 2.00 & 2.00 \\
\hline Soybean oil & 50.00 & 50.00 & 50.00 & 50.00 & 50.00 \\
\hline Dicalcium phosphate & 18.00 & 18.00 & 18.00 & 18.00 & 18.00 \\
\hline Common salt & 2.50 & 2.50 & 2.50 & 2.50 & 2.50 \\
\hline Vitamin and mineral supplement ${ }^{1}$ & 4.00 & 4.00 & 4.00 & 4.00 & 4.00 \\
\hline $\mathrm{BHT}^{2}$ & 0.20 & 0.20 & 0.20 & 0.20 & 0.20 \\
\hline Gross energy (kcal kg-1) & 4281.65 & 4281.65 & 4281.63 & 4281.61 & 4281.87 \\
\hline Crude protein ( $\mathrm{g} \mathrm{kg}^{-1}$ ) & 350.70 & 350.70 & 350.50 & 350.40 & 350.60 \\
\hline Crude fiber $\left(\mathrm{g} \mathrm{kg}^{-1}\right)$ & 40.00 & 40.00 & 40.10 & 40.10 & 40.40 \\
\hline Ether extract $\left(\mathrm{g} \mathrm{kg}^{-1}\right)$ & 78.70 & 78.70 & 78.80 & 78.80 & 78.80 \\
\hline Total calcium ( $\mathrm{g} \mathrm{kg}^{-1}$ ) & 15.10 & 15.10 & 15.10 & 15.10 & 15.10 \\
\hline Available phosphorus $\left(\mathrm{g} \mathrm{kg}^{-1}\right)$ & 7.20 & 7.20 & 7.20 & 7.10 & 7.10 \\
\hline Methionine $\left(\mathrm{g} \mathrm{kg}^{-1}\right)$ & 6.00 & 6.00 & 6.00 & 6.00 & 6.00 \\
\hline Lysine $\left(\mathrm{g} \mathrm{kg}^{-1}\right)$ & 17.10 & 17.10 & 17.10 & 17.10 & 17.10 \\
\hline
\end{tabular}


The experimental diets were formulated based on the nutritional requirements of Trichogaster lalius (Zuanon et al., 2013) (Table 1) and chemical composition of turmeric rhizome powder (Table 2). The turmeric rhizome powder (Açafrão da Terra Pirata ${ }^{\circledR}$ - Contagem, Minas Gerais, Brazil) was premixed with the other ingredients and then pelletized, dried in a forced-ventilation oven $\left(40{ }^{\circ} \mathrm{C}\right.$ for $\left.48 \mathrm{~h}\right)$, ground, and sieved to obtain pellets of $1 \pm 0.2 \mathrm{~mm}$ diameter.

Orange thick-lipped gourami, T. labiosa, juveniles were kept in 7-L aquaria, which were provided with aeration and biological filters, at a stocking density of $1.71{\text { fish } \mathrm{L}^{-1} \text { of water (12 fish aquarium }}^{-1}$ ). Temperature was controlled by heaters and thermostats $\left(26.3 \pm 0.15{ }^{\circ} \mathrm{C}\right)$. Fish were fed to satiation three times daily for $120 \mathrm{~d}$. The water temperature was checked daily at 08:00 h. Dissolved oxygen was measured biweekly using an oximeter. The $\mathrm{pH}$, total ammonia, and nitrite were measured using colorimetric kits. Conductivity was measured with a conductivity meter. Toxic ammonia was calculated using the formula:

$$
\text { Toxic ammonia }=\frac{\text { Total ammonia }}{\left(1+10\left((0.0902-\mathrm{pH})+\left(\frac{2730}{273.2+\text { temperature }}\right)\right)\right.}
$$

After verification of these water quality parameters, aquaria water was siphoned to remove any feces.

At the end of the experimental period, fish were counted, weighed, and measured using the following standard measurements for calculating these growth performance variables: survival rate, weight gain, feed intake, feed conversion ratio, protein efficiency ratio, specific growth rate, and body condition factor.

To evaluate fish skin pigmentation, four fish per aquarium (two males and two females) were euthanized by high amounts of anesthetic ( $400 \mathrm{mg} \mathrm{L}^{-1}$ clove oil), dried on paper napkins, and imaged according to the methodology of Rezende et al. (2012) with modifications. The images were collected in RAW format with a Panasonic DMC-FZ200 digital camera. Fish were placed individually on a white background (A4 sheet paper over a Styrofoam base) next to an 18\% grey card (medium grey). A luminaire with a fluorescent bulb $(45 \mathrm{~W})$ was positioned $35 \mathrm{~cm}$ above the surface on which the fish were placed, forming a $90^{\circ}$ angle with the axis of the animal body. To enhance the lighting and homogenize the light distribution, a Styrofoam base was positioned $15 \mathrm{~cm}$ from the belly of the animal, forming a $90^{\circ}$ angle with the Styrofoam base. To obtain maximum fidelity to the actual colors of the fish, the images in RAW format were treated in a standardized manner following the technique of balancing colors from the $18 \%$ grey card (medium grey) with Adobe Lightroom ${ }^{\circledR}$ software. As the RAW format decomposes the colors in the RGB system (red, blue, and green), digital files were converted to CMYK format (C, cyan; $\mathrm{M}$, magenta; Y, yellow; and K, black) to allow assessment of the color of interest in this study (ranging from yellow to magenta, according to the pigment present in turmeric). These levels of skin coloration were measured in two body parts (ventral and dorsal) of males and females. In each body part, two images (replicas) were taken to calculate the average values for each color index (Figure 1).

To calculate the gonadosomatic and viscerosomatic indices, we used the same fish that were euthanized for evaluation of skin pigmentation (two males and two females per aquarium). The viscera and gonads were subsequently removed and weighed on an analytical balance.

After evaluation of growth performance and skin color, the remaining fish were returned to the aquaria to recover from the stress of capture and handling biometrics and were fed the same test diets for another $55 \mathrm{~d}$ (totaling a period of $175 \mathrm{~d}$ of feeding). After this period, fish fasted for $48 \mathrm{~h}$, after which they

Table 2 - Chemical composition of turmeric rhizome powder (Açafrão da Terra Pirata ${ }^{\circledR}$ - Contagem, Minas Gerais, Brazil)

\begin{tabular}{lcccccc}
\hline & \multicolumn{5}{c}{ Proximal composition $\left(\mathrm{g} \mathrm{kg}^{-1}\right)$} \\
\cline { 2 - 7 } & Dry matter & Crude protein & Ether extract & Crude fiber & Phosphorus & Calcium \\
\hline Turmeric & 892.59 & 133.76 & 46.10 & 74.57 & 3.63 & 1.50 \\
\hline
\end{tabular}



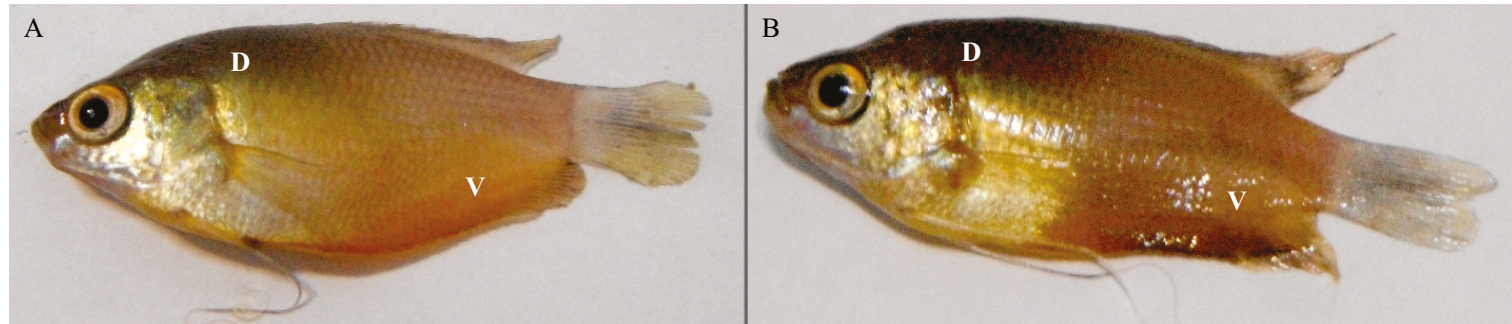

The levels of skin coloration (C, cyan; M, magenta; Y, yellow; and K, black) were measured in ventral (V) and dorsal (D) regions of females (A) and males (B)

Figure 1 - Color evaluation of the body parts of Trichogaster labiosa.

were placed in 15 plastic bags (five treatments and three replicates) with dimensions of $35.5 \times 25 \mathrm{~cm}$. Each bag was considered a replicate and contained $1 \mathrm{~L}$ of water $\left(8 \mathrm{fish} \mathrm{L}^{-1}\right)$, approximately $1 \mathrm{~L}$ of atmospheric air, and approximately $1 \mathrm{~L}$ of oxygen introduced by a hose coupled to an oxygen cylinder.

Fish remained in plastic bags for $24 \mathrm{~h}$, following the methodology described by Teo et al. (1989). The bags with the fish were kept in the trunk of a car, which alternated between periods of motion and no motion. After this period, bags were opened, and water samples were taken for the following analyses: dissolved oxygen, temperature, $\mathrm{pH}$, and total and toxic ammonia.

To measure blood glucose and lactate levels, two fish per bag (six fish per treatment) were euthanized by high amounts of anesthetic ( $400 \mathrm{mg} \mathrm{L}^{-1}$ clove oil). The caudal peduncle was subsequently cut with a scalpel, and blood was directly deposited on a reagent strip of a digital monitor device (Accutrend ${ }^{\circledR}$ Plus Roche - Mannheim, Germany).

To evaluate the stress effect of transport on the skin pigmentation changes, two males and two females per bag (12 fish per treatment) were imaged, and skin-coloring indices (SCI) were evaluated following the same procedures described earlier. Based on the coloring indices, skin depigmentation indices (SDI) were calculated using the following expression:

$$
\mathrm{SDI}=\mathrm{SCI}_{\mathrm{BT}}-\mathrm{SCI}_{\mathrm{AT}},
$$

in which $\mathrm{SCI}_{\mathrm{BT}}=$ skin coloring index before transport (\%), and $\mathrm{SCI}_{\mathrm{AT}}=$ skin coloring index after transport (\%).

Evaluations of the effects of turmeric levels in the diet on growth performance, body indices, and water quality before and after transport and stress responses after transport (blood glucose and lactate) were performed by analysis of variance (ANOVA) and polynomial regression at $5 \%$ probability. The Lilliefors test was applied to check the assumption of normality of errors. To check the homogeneity of error variances among treatments, Bartlett's test was applied. To choose regression models, we considered the significance of the regression coefficients, behavior of the variables under study, and magnitude of the correlation coefficients, calculated according to the regression sum of squares/treatments sum of squares.

The evaluations of turmeric in the diet and sex effects on the skin coloring indices and skin depigmentation indices were performed by a two-way ANOVA. When the F test was significant at $5 \%$ probability, polynomial regression was performed. Data were analyzed using SAEG (Sistema para Análises Estatísticas, version 9.1) statistical software package.

\section{Results}

No effects of turmeric supplementation in the diet were observed on survival rate, feed conversion ratio, body condition factor, viscerosomatic index, and male and female gonadosomatic indices $(\mathrm{P}>0.05)$ (Table 3). Quadratic effects of dietary turmeric for weight gain, final length, specific growth rate, and feed intake $(\mathrm{P}<0.05)$ were observed, with estimated values for minimizing the variables equal to 15.53 , $16.39,14.94$, and $16.21 \mathrm{~g} \mathrm{~kg}^{-1}$ of diet, respectively (Table 3). 
For dissolved oxygen $(\mathrm{P}<0.05)$ in aquaria water, a quadratic effect of dietary turmeric in the diet was observed, with the estimated value for maximizing this variable equal to $1.39 \mathrm{~g} \mathrm{~kg}^{-1}$ (Table 4). No significant interactions were observed between the effects of turmeric and sex on skin coloring $(\mathrm{P}>0.05)$. No effects of dietary turmeric were observed in the skin coloring indices of cyan ventral $\left(\mathrm{SCI}_{\mathrm{CV}}\right)$, magenta ventral $\left(\mathrm{SCI}_{\mathrm{MV}}\right)$, yellow ventral $\left(\mathrm{SCI}_{\mathrm{YV}}\right)$, black ventral $\left(\mathrm{SCI}_{\mathrm{KV}}\right)$, magenta dorsal $\left(\mathrm{SCI}_{\mathrm{MD}}\right)$, and yellow dorsal $\left(\mathrm{SCI}_{\mathrm{YD}}\right)$ for T. labiosa $(\mathrm{P}>0.05)$. For the cyan dorsal $\left(\mathrm{SCI}_{\mathrm{CD}}\right)$ and black dorsal $\left(\mathrm{SCI}_{\mathrm{KD}}\right)$, quadratic effects $(\mathrm{P}<0.05)$ of dietary turmeric in the diet were observed, with the estimated values that maximize these variables equal to 15.03 and $17.44 \mathrm{~g} \mathrm{~kg}^{-1}$ of turmeric, respectively (Table 5). No effects of sex for dorsal coloring indices ( $\mathrm{P}>0.05$ ) were observed. Males had higher values of $\mathrm{SCI}_{\mathrm{CV}}, \mathrm{SCI}_{\mathrm{MV}} \mathrm{SCI}_{\mathrm{YV}^{\prime}}$ and $\mathrm{SCI}_{\mathrm{KV}}$ compared with females (Table 5).

After simulation of transport, fish mortality was not observed in any treatment. No significant interactions $(\mathrm{P}>0.05)$ were observed between the effects of the turmeric and sex on the skin depigmentation indexes. There were no effects of turmeric supplementation on magenta ventral $\left(\mathrm{SDIM}_{\mathrm{MV}}\right)$, black ventral $\left(\mathrm{SDI}_{\mathrm{KV}}\right)$, magenta dorsal $\left(\mathrm{SDI}_{\mathrm{MD}}\right)$, and yellow dorsal $\left(\mathrm{SDI}_{\mathrm{YD}}\right)$ skin depigmentation indexes $(\mathrm{P}>0.05)$ of T. labiosa. For the cyan dorsal $\left(\mathrm{SDI}_{\mathrm{CD}}\right)$ and black dorsal $\left(\mathrm{SDI}_{\mathrm{KD}}\right.$ ) skin depigmentation indices, quadratic effects $(\mathrm{P}<0.05)$ of dietary turmeric were observed, with the estimated values for maximizing the respective variables equal to 13.29 and $17.04 \mathrm{~g} \mathrm{~kg}^{-1}$ (Table 6).

Table 3 - Productive performance of Trichogaster labiosa fed diets containing increasing levels of Curcuma longa

\begin{tabular}{|c|c|c|c|c|c|c|c|c|}
\hline & \multicolumn{5}{|c|}{ Level of turmeric in the diets $\left(\mathrm{g} \mathrm{kg}^{-1}\right)$} & \multirow{2}{*}{ CV (\%) } & \multicolumn{2}{|c|}{ P-value } \\
\hline & 0.0 & 1.0 & 5.0 & 10.0 & 25.0 & & $\mathrm{~L}$ & $\mathrm{Q}$ \\
\hline Survival rate $(\%)^{\mathrm{ns}}$ & 93.75 & 87.50 & 95.83 & 93.75 & 89.59 & 10.65 & - & - \\
\hline Weight gain $(g)^{1}$ & 1.60 & 1.41 & 1.29 & 1.17 & 1.24 & 11.68 & 0.038 & 0.004 \\
\hline Final length $(\mathrm{cm})^{2}$ & 3.96 & 3.82 & 3.76 & 3.72 & 3.71 & 3.42 & 0.056 & 0.040 \\
\hline Specific growth rate $(\% / d)^{3}$ & 1.01 & 0.93 & 0.88 & 0.83 & 0.86 & 10.99 & 0.094 & 0.036 \\
\hline Feed intake $(g)^{4}$ & 4.39 & 3.82 & 3.68 & 3.53 & 3.55 & 9.67 & 0.055 & 0.027 \\
\hline Feed conversion rate ${ }^{\mathrm{ns}}$ & 2.76 & 2.73 & 2.87 & 3.05 & 2.88 & 8.52 & - & - \\
\hline Conditional factor ${ }^{\mathrm{ns}}$ & 3.69 & 3.77 & 3.73 & 3.62 & 3.78 & 4.56 & - & - \\
\hline Viscerosomatic index (\%) $)^{\mathrm{ns}}$ & 8.98 & 8.60 & 8.94 & 8.76 & 9.09 & 8.46 & - & - \\
\hline Gonadosomatic index of males $(\%)^{\mathrm{ns}}$ & 1.06 & 0.99 & 0.99 & 1.36 & 1.25 & 24.08 & - & - \\
\hline Gonadosomatic index of females (\%) ${ }^{\mathrm{ns}}$ & 19.77 & 16.35 & 15.18 & 19.27 & 18.75 & 13.73 & - & - \\
\hline
\end{tabular}

$\mathrm{CV}$ - coefficient of variation.

ns - not significant for levels of turmeric diet by analysis of variance at $5 \%$ probability.

$\mathrm{L}$ and $\mathrm{Q}$ - linear and quadratic effects, concerning the inclusion of turmeric in the diet.

${ }^{1} \mathrm{WG}=0.0018 \mathrm{x}^{2}-0.0559 \mathrm{x}+1.5304 ; \mathrm{R}^{2}=0.92$

${ }^{2} \mathrm{FL}=0.0009 \mathrm{x}^{2}-0.0295 \mathrm{x}+3.9009 ; \mathrm{R}^{2}=0.83$

${ }^{3} \mathrm{SGR}=0.0008 \mathrm{x}^{2}-0.0239 \mathrm{x}+0.9851 ; \mathrm{R}^{2}=0.92$

${ }^{4} \mathrm{FI}=0.0031 \mathrm{x}^{2}-0.1005 \mathrm{x}+4.1554 ; \mathrm{R}^{2}=0.76$.

Table 4 - Water quality of Trichogaster labiosa fed diets containing increasing levels of Curcuma longa

\begin{tabular}{|c|c|c|c|c|c|c|c|c|}
\hline & \multicolumn{5}{|c|}{ Level of turmeric in the diets $\left(\mathrm{g} \mathrm{kg}^{-1}\right)$} & \multirow{2}{*}{ CV (\%) } & \multicolumn{2}{|c|}{ P-value } \\
\hline & 0.0 & 1.0 & 5.0 & 10.0 & 25.0 & & $\mathrm{~L}$ & Q \\
\hline $\mathrm{pH}^{\mathrm{ns}}$ & 6.48 & 6.48 & 6.51 & 6.53 & 6.41 & 0.96 & - & - \\
\hline Dissolved $\mathrm{O}_{2}\left(\mathrm{mg} \mathrm{L}^{-1}\right)^{1}$ & 6.20 & 6.22 & 6.43 & 6.01 & 5.65 & 4.51 & 0.001 & 0.005 \\
\hline Toxic ammonia (ppm) ns & 0.003 & 0.003 & 0.003 & 0.004 & 0.004 & 56.84 & - & - \\
\hline Conductivity $\left(\mu \mathrm{S} \mathrm{cm}^{-1}\right)^{\mathrm{ns}}$ & 2.79 & 3.91 & 2.87 & 2.82 & 3.00 & 39.23 & - & - \\
\hline
\end{tabular}

$\mathrm{CV}$ - coefficient of variation.

ns - not significant by analysis of variance at $5 \%$ probability.

$\mathrm{L}$ and $\mathrm{Q}$ - linear and quadratic effects, concerning the inclusion of turmeric in the diet.

${ }^{1} \mathrm{O}_{2}=-0.0009 \mathrm{x}^{2}-0.0025 \mathrm{x}+6.2595 ; \mathrm{R}^{2}=0.82$. 
Table 5 - Skin coloring indexes in the CMYK (C, cyan; M, magenta; Y, yellow; and K, black) patterns of the ventral and dorsal regions of males and females of Trichogaster labiosa fed diets containing increasing levels of Curcuma longa

\begin{tabular}{|c|c|c|c|c|c|c|c|c|c|}
\hline & & \multicolumn{4}{|c|}{ Skin coloring index of ventral region } & \multicolumn{4}{|c|}{ Skin coloring index of dorsal region } \\
\hline & & $\mathrm{SCI}_{\mathrm{vc}}$ & $\mathrm{SCI}_{\mathrm{vM}}$ & $\mathrm{SCI}_{\mathrm{VY}}$ & $\mathrm{SCI}_{\mathrm{VK}}$ & $\mathrm{SCI}_{\mathrm{DC}}{ }^{1}$ & $\mathrm{SCI}_{\mathrm{DM}}$ & $\mathrm{SCI}_{\mathrm{DY}}$ & $\mathrm{SCI}_{\mathrm{DK}}{ }^{2}$ \\
\hline \multicolumn{2}{|c|}{$\begin{array}{l}\text { Effect of the interaction } \\
\text { between turmeric and sex }\end{array}$} & ns & ns & ns & ns & ns & ns & ns & ns \\
\hline \multicolumn{2}{|c|}{ Effect of turmeric $\left(\mathrm{g} \mathrm{kg}^{-1}\right)$} & ns & ns & ns & ns & $\mathrm{P}<0.05$ & ns & ns & $\mathrm{P}<0.05$ \\
\hline \multirow{2}{*}{ P-value } & $\mathrm{L}$ & - & - & - & - & 0.090 & - & - & 0.0003 \\
\hline & $\mathrm{Q}$ & - & - & - & - & 0.008 & - & - & 0.0001 \\
\hline \multicolumn{2}{|l|}{0.0} & 3.94 & 42.38 & 63.63 & 0.31 & 40.00 & 63.69 & 80.38 & 37.38 \\
\hline \multicolumn{2}{|l|}{1.0} & 5.38 & 37.19 & 57.75 & 0.56 & 45.13 & 61.31 & 74.94 & 32.88 \\
\hline \multicolumn{2}{|l|}{5.0} & 5.31 & 42.5 & 63.00 & 0.31 & 50.25 & 66.00 & 73.63 & 51.88 \\
\hline \multicolumn{2}{|l|}{10.0} & 5.13 & 42.00 & 62.06 & 0.25 & 50.56 & 65.50 & 74.81 & 51.75 \\
\hline \multicolumn{2}{|l|}{25.0} & 5.44 & 41.63 & 62.57 & 0.44 & 48.57 & 65.63 & 75.38 & 54.5 \\
\hline \multicolumn{2}{|c|}{ Effect of sex } & $\mathrm{P}<0.05$ & $\mathrm{P}<0.05$ & $\mathrm{P}<0.05$ & $\mathrm{P}<0.05$ & ns & ns & ns & ns \\
\hline \multicolumn{2}{|l|}{ Males } & $9.21 \mathrm{a}$ & $47.23 a$ & $69.69 a$ & $0.92 \mathrm{a}$ & $45.79 a$ & $66.27 a$ & $75.56 a$ & $43.88 a$ \\
\hline \multicolumn{2}{|l|}{ Females } & $2.10 \mathrm{~b}$ & $36.73 \mathrm{~b}$ & $58.75 \mathrm{~b}$ & $0.02 b$ & $47.25 \mathrm{a}$ & $63.15 a$ & $76.90 \mathrm{a}$ & $47.23 a$ \\
\hline \multicolumn{2}{|l|}{ CV (\%) } & 87.60 & 18.32 & 23.33 & 234.76 & 15.00 & 6.74 & 10.98 & 20.64 \\
\hline
\end{tabular}

$\mathrm{SCI}_{\mathrm{vC}}$ - skin coloring index of ventral cyan; $\mathrm{SCI}_{\mathrm{vM}}$ - skin coloring index ventral magenta; $\mathrm{SCI}_{\mathrm{VY}}$ - skin coloring index ventral yellow; $\mathrm{SCI}_{\mathrm{VK}}$ - skin coloring index ventral black; $\mathrm{SCI}_{\mathrm{DC}}$ - skin coloring index dorsal cyan; $\mathrm{SCI}_{\mathrm{DM}}$ - skin coloring index dorsal magenta; $\mathrm{SCI}_{\mathrm{DY}}$ - skin coloring index dorsal yellow; and $\mathrm{SCI}_{\mathrm{DK}}$ - skin coloring index dorsal black; CV - coefficient of variation.

$\mathrm{ns}-$ not significant by analysis of variance at $5 \%$ probability.

${ }^{1} \mathrm{SCI}_{\mathrm{DC}}=-0.0497 \mathrm{x}^{2}+1.494 \mathrm{x}+42.115 ; \mathrm{R}^{2}=0.84$.

${ }^{2} \mathrm{SCI}_{\mathrm{DK}}=-0.0772 \mathrm{x}^{2}+2.6935 \mathrm{x}+35.183 ; \mathrm{R}^{2}=0.84$

Table 6 - Skin depigmentation indexes in the CMYK (C, cyan; M, magenta; Y, yellow; and K, black) patterns of the ventral and dorsal regions of males and females of Trichogaster labiosa fed diets containing increasing levels of Curcuma longa, after transport

\begin{tabular}{|c|c|c|c|c|c|c|c|c|c|}
\hline & & \multicolumn{4}{|c|}{$\begin{array}{l}\text { Skin depigmentation index of ventral } \\
\text { region }\end{array}$} & \multicolumn{4}{|c|}{$\begin{array}{l}\text { Skin depigmentation index of dorsal } \\
\text { region }\end{array}$} \\
\hline & & $\mathrm{SDI}_{\mathrm{vc}}$ & $\mathrm{SDI}_{\mathrm{VM}}$ & $\mathrm{SDI}_{\mathrm{VY}}$ & $\mathrm{SDI}_{\mathrm{VK}}$ & $\mathrm{SDI}_{\mathrm{DC}}{ }^{1}$ & $\mathrm{SDI}_{\mathrm{DM}}$ & $\mathrm{SDI}_{\mathrm{DY}}$ & $\mathrm{SDI}_{\mathrm{DK}}{ }^{2}$ \\
\hline \multicolumn{2}{|c|}{$\begin{array}{l}\text { Effect of the interaction } \\
\text { between turmeric and sex }\end{array}$} & ns & ns & ns & ns & ns & ns & ns & ns \\
\hline \multicolumn{2}{|c|}{ Effect of turmeric $\left(\mathrm{g} \mathrm{kg}^{-1}\right)$} & ns & ns & ns & ns & $\mathrm{P}<0.05$ & ns & ns & $\mathrm{P}<0.05$ \\
\hline \multirow{2}{*}{ P-value } & $\mathrm{L}$ & - & - & - & - & 0.040 & - & - & 0.0020 \\
\hline & Q & - & - & - & - & 0.003 & - & - & 0.0002 \\
\hline \multicolumn{2}{|l|}{0.0} & -4.88 & -0.29 & 5.00 & -0.25 & 3.79 & 17.33 & 15.25 & 25.25 \\
\hline \multicolumn{2}{|l|}{1.0} & -4.88 & 6.92 & 10.04 & 0.13 & 4.17 & 18.50 & 11.88 & 24.63 \\
\hline \multicolumn{2}{|l|}{5.0} & -2.58 & 0.75 & 2.04 & 0.00 & 11.83 & 21.42 & 19.50 & 36.13 \\
\hline \multicolumn{2}{|l|}{10.0} & 0.33 & 0.46 & 1.25 & 0.21 & 13.46 & 19.04 & 13.42 & 37.50 \\
\hline \multicolumn{2}{|l|}{25.0} & -2.92 & 6.71 & 13.50 & 0.25 & 11.33 & 20.75 & 9.54 & 38.33 \\
\hline \multicolumn{2}{|c|}{ Effect of sex } & ns & $\mathrm{P}<0.05$ & ns & ns & ns & ns & ns & $\mathrm{P}<0.05$ \\
\hline \multicolumn{2}{|c|}{ Males } & $-3.17 \mathrm{a}$ & $4.79 a$ & $6.76 \mathrm{a}$ & $0.06 \mathrm{a}$ & $7.31 \mathrm{a}$ & $19.65 a$ & $12.90 \mathrm{a}$ & $29.22 b$ \\
\hline \multicolumn{2}{|l|}{ Females } & $-2.33 a$ & $0.18 \mathrm{~b}$ & $4.60 \mathrm{a}$ & $0.00 \mathrm{a}$ & $9.76 a$ & $20.06 a$ & $14.21 \mathrm{a}$ & $34.92 \mathrm{a}$ \\
\hline \multicolumn{2}{|l|}{ CV (\%) } & -166.20 & 193.14 & 167.39 & 1299.04 & 68.08 & 21.28 & 85.88 & 18.13 \\
\hline
\end{tabular}

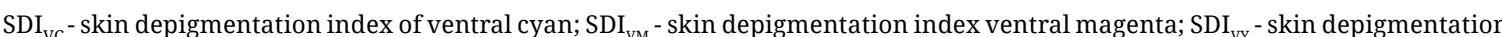
index ventral yellow; $\mathrm{SDI}_{\mathrm{VK}}$ - skin depigmentation index ventral black; $\mathrm{SDI}_{\mathrm{DC}}$ - skin depigmentation index dorsal cyan; $\mathrm{SDI}_{\mathrm{DM}}$ - skin

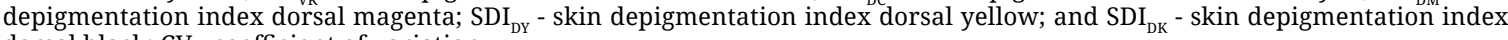
dorsal black; CV - coefficient of variation.

ns - not significant by analysis of variance at $5 \%$ probability.

${ }^{1} \mathrm{SDI}_{\mathrm{CD}}=-0.0513 \mathrm{x}^{2}+1.5899 \mathrm{x}+3.5907 ; \mathrm{R}^{2}=0.95$

${ }^{2} \mathrm{SDI}_{\mathrm{KD}}^{\mathrm{CD}}=-0.0598 \mathrm{x}^{2}+2.0382 \mathrm{x}+24.6416 ; \mathrm{R}^{2}=0.92$. 
After the transport simulation, quadratic effects of dietary turmeric were observed only on water $\mathrm{pH}$ $(\mathrm{P}<0.05)$ in plastic bags, with the estimated value for maximizing this variable equal to $16.99 \mathrm{~g} \mathrm{~kg}^{-1} \mathrm{diet}$ (Table 7).

No effects of turmeric supplementation on concentrations of blood lactate and glucose $(\mathrm{P}>0.05)$ after transport simulation were observed (Table 8).

\section{Discussion}

The growth reduction in T. labiosa fed diets supplemented with turmeric probably occurred due to lower feed intake. Sambaiah et al. (1982) attributed the reduction of feed intake of rats to the low palatability of turmeric. Kang et al. (2011) observed that curcumin, the main constituent of turmeric, reduced feed intake of goldfish, Carassius auratus, probably by inducing the release of corticotrophinreleasing hormone (CRH), a potent anorexigenic neuropeptide (Matsuda, 2009). In laying hens, turmeric also reduced food intake and weight gain (Qasem et al., 2015). Despite the reduction in growth of $T$. labiosa, supplementation with turmeric did not affect the weight gain of the Nile tilapia (Oreochromis niloticus; Mahmoud et al., 2014) and improved the growth performance of guppy (Poecilia reticulata; Mukherjee et al., 2009).

The reduction in oxygen content of the water in aquaria indicates that turmeric caused an increase in fish metabolism. It is possible that turmeric acted on the lipid metabolism of animals, increasing their oxidation and, thus, increasing oxygen consumption by the fish. Reduced levels of triglycerides and lowdensity lipoprotein cholesterol have been previously demonstrated in laying hens (Riasi et al., 2012), rats (Kim and Kim, 2010), and hamsters (Jang et al., 2008) fed diets containing turmeric or curcumin. Mahmoud et al. (2014) also found reduced total lipids in carcasses of Nile tilapia fed diets with turmeric. The increased oxidation and decreased fatty acid synthesis in the liver of hamsters was demonstrated by Jang et al. (2008), with reduced fatty acid synthase activity and increased fatty $\beta$ oxidation activity. Similar results were observed by Ejaz et al. (2009) with increased carnitine palmitoyltransferase-1 expression and reduction of glycerol-3-phosphate acyl transferase-1 activity. However, turmeric did not cause a reduction in dissolved oxygen content in the water in plastic bags after transportation. This may be related to the injection of oxygen into the packages before transportation. Thus, even though

Table 7 - Water quality after transport of Trichogaster labiosa fed diets containing increasing levels of Curcuma longa

\begin{tabular}{lcccccccc}
\hline & \multicolumn{4}{c}{ Level of turmeric in the diets $\left(\mathrm{g} \mathrm{kg}^{-1}\right)$} & & \multicolumn{2}{c}{ P-value } \\
\cline { 2 - 5 } & 0.0 & 1.0 & 5.0 & 10.0 & 25.0 & & $\mathrm{~L}$ & $\mathrm{Q}$ \\
\hline $\mathrm{pH}^{1}$ & 6.40 & 6.53 & 6.60 & 6.60 & 6.60 & 1.47 & 0.039 & 0.025 \\
Dissolved $\mathrm{O}_{2}\left(\mathrm{mg} \mathrm{L}^{-1}\right)^{\mathrm{ns}}$ & 5.35 & 6.22 & 5.19 & 4.59 & 4.25 & 33.09 & - & - \\
Toxic ammonia $(\mathrm{ppm})^{\mathrm{ns}}$ & 0.007 & 0.009 & 0.008 & 0.009 & 0.010 & 122.98 & - & - \\
\hline
\end{tabular}

$\mathrm{CV}$ - coefficient of variation.

ns - not significant by analysis of variance at $5 \%$ probability.

$\mathrm{L}$ and $\mathrm{Q}$ - linear and quadratic effects, concerning the inclusion of turmeric in the diet.

${ }^{1} \mathrm{pH}=0.00068 \mathrm{x}^{2}+0.02310 \mathrm{x}+6.4482 ; \mathrm{R}^{2}=0.73$.

Table 8 - Blood lactate and glucose levels of Trichogaster labiosa fed diets containing increasing levels of Curcuma longa

\begin{tabular}{lcccccc}
\hline & \multicolumn{4}{c}{ Level of turmeric in the diets $\left(\mathrm{g} \mathrm{kg}^{-1}\right)$} & \multirow{2}{*}{ CV (\%) } \\
\cline { 2 - 6 } & 0.0 & 1.0 & 5.0 & 10.0 & 25.0 & \\
\hline Lactate $\left(\mathrm{mmol} \mathrm{L}^{-1}\right)^{\mathrm{ns}}$ & 0.87 & 1.37 & 1.75 & 1.65 & 1.70 & 52.30 \\
Glucose $\left(\mathrm{mg} \mathrm{dL}^{-1}\right)^{\mathrm{ns}}$ & 51.76 & 33.00 & 46.22 & 41.78 & 42.89 & 38.51 \\
\hline
\end{tabular}

$\mathrm{CV}$ - coefficient of variation.

ns - not significant by analysis of variance at $5 \%$ probability. 
the turmeric-fed fish may have consumed more oxygen, this effect was not observed because the water was saturated with oxygen.

Because the pigments present in turmeric are yellow-orange, an effect of turmeric supplementation in cyan color was not expected. However, the wild variety of this species shows a pattern of staining of orange and cyan vertical bars. Thus, as turmeric was not efficient in orange pigmentation, it is possible that in the absence of proper pigmentation of orange chromatophores (xanthophores and erythrophores), the underlying chromatophores with cyan pigments (cyanophores) stand out. This phenomenon, known as blue color syndrome, has been observed in Penaeus monodon shrimp, which normally have greenish-brown color, but, under conditions of carotenoid deficiency, they exhibit blue staining (Howell and Matthews, 1991). The increase of the black dorsal coloring index $\left(\mathrm{SCI}_{\mathrm{KD}}\right)$ shows that the fish were darker, probably due to increased melanin in melanophores and/or dispersion of pigment granules. This effect was probably caused by curcumin, since Jang et al. (2008) demonstrated that this substance regulates proteins that modulate melanogenesis in B16F10 mouse melanoma cells. Although turmeric did not promote skin pigmentation in T. labiosa, Mukherjee et al. (2009) reported that turmeric powder at a concentration of $0.9 \mathrm{~g} \mathrm{~kg}^{-1}$ of feed resulted in the highest pigment concentration in caudal fin and muscle of $P$. reticulata.

Although there was no significant effect of the interaction between curcuma and sex, differences between males and females were observed in cyan, magenta, yellow, and black skin coloring indices of the ventral region. As many species of fish exhibit different color patterns between males and females (generally, males are the more colorful), this result was already expected. Skin color is an important feature in interactions among fish, since it signals social status. In addition, in males, the most intense pigmentation makes them more attractive to females (Rodrigues et al., 2009). The preference of females for males with more intense red coloration of the skin was observed in gourami (Colisa lalia) (currently classified as Trichogaster lalius; Baron et al., 2008), guppy (Houde, 1997), Gasterosteus aculeatus (McLennan and McPhail, 1990), and Betta splendens (Clotfelter et al., 2007).

Although some studies have shown that turmeric attenuates stress responses in mammals with reduction of serum levels of CRH or cortisol (Xia et al., 2006; Xia et al., 2007; Wei et al. 2010), our results indicated that turmeric did not influence the hypothalamus-pituitary-interrenal axis of T. labiosa and, therefore, does not influence the values of blood glucose and lactate. However, some studies have shown that curcumin stimulates the adrenal glands to secrete cortisol or cortisone in mammals (Srivastava and Srimal, 1985; Enyeart et al., 2008). The different effects of curcuma/curcumin on stress control, in different studies, may be related to the curcumin concentrations in different turmeric sources used.

The stress caused by transport frequently induces skin color reduction in ornamental fish (Dharmaraj and Dhevendaran, 2011). In the present study, the supplementation with turmeric at levels up to $17 \mathrm{~g} \mathrm{~kg}^{-1}$ caused greater reduction in skin color of T. labiosa, even with no increase in stress responses (glucose and lactate). Thus, turmeric may cause reduction in skin color by another way, such as the $\alpha$-MSH signal pathway. Jang et al. (2009) observed that curcumin reduced the melanin content in B16F10 cells. The referred study shows that hypopigmentation caused by turmeric extract occurred by suppression of melanin synthesis mediated by the activation of the intracellular signaling pathways mitogen-activated protein kinase/extracellular signal-regulated kinase and phosphatidylinositol 3-kinase/Akt. The activation of this signal pathway caused the suppression of microphthalmia-associated transcription factor expression, including the tyrosinase and tyrosinase-related proteins.

\section{Conclusions}

Curcuma longa does not act as a growth promoter or a stress reducer for Trichogaster labiosa and does not improve the orange pattern of the skin pigmentation in the orange thick-lipped gourami strain of T. labiosa. 


\section{Acknowledgments}

We thank the Guabi Nutrição Animal, Brazil, for its support to perform these experiments successfully; Coordenação de Aperfeiçoamento de Pessoal de Nível Superior (CAPES), for granting the scholarship to the first author; and Professor Antonio Policarpo Souza Carneiro, for his support in the statistical analyses.

\section{References}

Aly, S. M. and Mohamed, M. F. 2010. Echinacea purpurea and Allium sativum as immunostimulants in fish culture using Nile tilapia (Oreochromis niloticus). Journal of Animal Physiology and Animal Nutrition 94:31-39. https://doi.org/10.1111/j.1439-0396.2009.00971.x

Baron, M.; Davies, S.; Alexander, L.; Snellgrove, D. and Sloman, K. A. 2008. The effect of dietary pigments on the coloration and behavior of flame-red dwarf gourami, Colisa lalia. Animal Behaviour 75:1041-1051. https://doi.org/10.1016/j.anbehav.2007.08.014

Barton, B. A. 2002. Stress in fishes: a diversity of responses with particular reference to changes in circulating corticosteroids. Integrative and Comparative Biology 42:517-525. https://doi.org/10.1093/icb/42.3.517

Becker, A. G.; Parodi, T. V.; Zeppenfeld, C. C.; Salbego, J.; Cunha, M. A.; Heldwein, C. G.; Loro, V. L.; Heinzmann, B. M. and Baldisserotto, B. 2016. Pre-sedation and transport of Rhamdia quelen in water containing essential oil of Lippia alba: metabolic and physiological responses. Fish Physiology and Biochemistry 42:73-81. https://doi.org/10.1007/s10695015-0118-x

Brandão, F. R.; Gomes, L. D. C.; Crescêncio, R. and Carvalho, E. D. S. 2008. Uso de sal durante o transporte de juvenis ( $1 \mathrm{~kg})$ de pirarucu (Arapaima gigas). Acta Amazonica 38:767-772. https://doi.org/10.1590/S0044-59672008000400022

Clotfelter, E. D.; Ardia, D. R. and McGraw, K. J. 2007. Red fish, blue fish: trade-offs between pigmentation and immunity in Betta splendens. Behavioral Ecology 18:1139-1145. https://doi.org/10.1093/beheco/arm090

Dharmaraj, S. and Dhevendaran, K. 2011. Application of microbial carotenoids as a source of colouration and growth of ornamental fish Xiphophorus helleri. World Journal of Fish and Marine Sciences 3:137-144.

Ejaz, A.; Wu, D.; Kwan, P. and Meydani, M. 2009. Curcumin inhibits adipogenesis in 3T3-L1 adipocytes and angiogenesis and obesity in C57/BL mice. The Journal of Nutrition 139:919-925. https://doi.org/10.3945/jn.108.100966

Enyeart, J. A.; Liu, H. and Enyeart, J. J. 2008. Curcumin inhibits bTREK-1 $\mathrm{K}^{+}$channels and stimulates cortisol secretion from adrenocortical cells. Biochemical and Biophysical Research Communications 370:623-628. https://doi.org/10.1016/j.bbrc.2008.04.001

Gaikwad, A.; Bodhankar, M.; Ittadwar, A. and Waikar, S. 2014. Antibacterial activity of isoflavone extracted from Curcuma longa linn. Zingeberaceae. Journal of Microbiology, Biotechnology and Food Sciences 1:06-09.

Gomes, L. C.; Araujo-Lima, C. A. R. M.; Roubach, R. and Urbinati, E. C. 2003. Avaliação dos efeitos da adição de sal e da densidade no transporte de tambaqui. Pesquisa Agropecuária Brasileira 38:283-290. https://doi.org/10.1590/S0100-204X2003000200016

Houde, A. E. 1997. Sex, colour, and mate choice in Guppies. Princeton University Press, New Jersey, USA.

Howell, B. K. and Matthews, A. D. 1991. The carotenoids of wild and blue disease affected farmed tiger shrimp (Penaeus monodon, Fabricius). Comparative Biochemistry and Physiology 98B:375-379. https://doi.org/10.1016/03050491(91)90193-H

Jang, E. M.; Choi, M. S.; Jung, U. J.; Kim, M. J.; Kim, H. J.; Jeon, S. M.; Shin, S. K.; Seong, C. N. and Lee, M. K. 2008. Beneficial effects of curcumin on hyperlipidemia and insulin resistance in high-fat-fed hamsters. Metabolism 57:1576-1583. https://doi.org/10.1016/j.metabol.2008.06.014

Jang, J. Y.; Lee, J. H.; Jeong, S. Y.; Chung, K. T.; Choi, Y. H. and Choi, B. T. 2009. Partially purified Curcuma longa inhibits alpha-melanocyte-stimulating hormone-stimulated melanogenesis through extracellular signal-regulated kinase or Akt activation-mediated signalling in B16F10 cells. Experimental Dermatology 18:689-694. https://doi.org/10.1111/j.1600-0625.2009.00857.x

Kang, K. S.; Yahashi, S.; Azuma, M.; Sakashita, A.; Shioda, S. and Matsuda, K. 2011. Effect of intraperitoneal injection of curcumin on food intake in a goldfish model. Journal of Molecular Neuroscience 45:172-176. https://doi.org/10.1007/s12031-010-9390-5

Kim, M. and Kim, Y. 2010. Hypocholesterolemic effects of curcumin via up-regulation of cholesterol 7a-hydroxylase in rats fed a high fat diet. Nutrition Research and Practice 4:191-195. https://doi.org/10.4162\%2Fnrp.2010.4.3.191

Lima, L. C.; Ribeiro, L. P.; Leite, R. C. and Melo, D. C. 2006. Estresse em peixes. Revista Brasileira de Reprodução Animal 30:113-117.

R. Bras. Zootec., 48:e20160282, 2019 
Mahmoud, M. M. A.; El-Lamie, M. M. M.; Dessouki, A. A. and Yusuf, M. S. 2014. Effect of Turmeric (Curcuma longa) supplementation on growth performance, feed utilization, and resistance of Nile tilapia (Oreochromis niloticus) to Pseudomonas fluorescens challenge. Global Research Journal of Fishery Science and Aquaculture 1:26-33.

Matsuda, K. 2009. Recent advances in the regulation of feeding behavior by neuropeptides in fish. Annals of the New York Academy of Sciences 1163:241-250. https://doi.org/10.1111/j.1749-6632.2008.03619.x

McLennan, D. A. and McPhail, J. D. 1990. Experimental investigations of the evolutionary significance of sexually dimorphic nuptial coloration in Gasterosteus aculeatus L.: the relationship between male colour and female behaviour Canadian Journal of Zoology 68:482-492. https://doi.org/10.1139/z90-071

Moreira, A. G. L.; Coelho, A. A. C.; Albuquerque, L. F. G.; Moreira, R. T. and Farias, W. R. L. 2015. Efeito do eugenol como agente mitigador do estresse no transporte de juvenis de tilápia do Nilo. Pesquisa Veterinária Brasileira 35:893-898. https://doi.org/10.1590/S0100-736X2015001100004

Mukherjee, A.; Mandal, B. and Banerjee, S. 2009. Turmeric as a carotenoid source on pigmentation and growth of fantail guppy, Poecilia reticulata. Proceedings of the Zoological Society of London 62:119-123. https://doi.org/10.1007/s12595-009-0013-5

Naghetini, C. C. 2006. Caracterização físico-química e atividade antifúngica dos óleos essenciais da cúrcuma. Dissertação (M.Sc.). Universidade Federal de Viçosa, Viçosa, MG, Brazil.

Nonose, N.; Pereira, J. A.; Machado, P. R. M.; Rodrigues, M. R.; Sato, D. T. and Martinez, C. A. R. 2014. Oral administration of curcumin (Curcuma longa) can attenuate the neutrophil inflammatory response in zymosan-induced arthritis in rats. Acta Cirúrgica Brasileira 29:727-734. https://doi.org/10.1590/S0102-86502014001800006

Pransin, M. 2006. Using Turmeric (Curcuma longa) in Goldfish (Carassius auratus) Feed. Thesis (M.Sc.) University of Kansas, Lawrence, Kansas, USA.

Qasem, M. M. A.; Alhajj, M. S.; Ger El Nabi, A. R. and Al-Mufarrej, S. I. 2015. Effect of turmeric powder as a dietary supplement on performance indicators and immune responses in broiler chickens. Journal of Animal and Veterinay Advances 14:30-35.

Ramadan, G.; Al-Kahtani, M. A. and El-Sayed, W. M. 2011. Anti-inflammatory and anti-oxidant properties of Curcuma longa (Turmeric) versus Zingiber officinale (Ginger) rhizomes in rat adjuvant-induced arthritis. Inflammation 34:291-301. https://doi.org/10.1007/s10753-010-9278-0

Rao, Y. V.; Das, B. K.; Jyotyrmayee, P. and Chakrabarti, R. 2006. Effect of Achyranthes aspera on the immunity and survival of Labeo rohita infected with Aeromonas hydrophila. Fish \& Shellfish Immunology 20:263-273. https://doi.org/10.1016/j.fsi.2005.04.006

Rezende, F. P.; Vidal Júnior, M. V.; Andrade, D. R.; Mendonça, P. P. and Santos, M. V. B. 2012. Characterization of a new methodology based on the intensity of skin staining of ornamental fish with applications in nutrition. Journal of Agricultural Science and Technology 2:606-613.

Riasi, A.; Kermanshahi, H. and Mahdavi, A. H. 2012. Production performance, egg quality and some serum metabolites of older commercial laying hens fed different levels of turmeric rhizome (Curcuma longa) powder. Journal of Medicinal Plants Research 6:2141-2145.

Rodrigues, R. R.; Carvalho, L. N.; Zuanon, J. and Del-Claro, K. 2009. Color changing and behavioral context in the Amazonian Dwarf Cichlid Apistogramma hippolytae (Perciformes). Neotropical Ichthyology 7:641-646. https://doi.org/10.1590/S1679-62252009000400013

Rüber, L.; Britz, R. and Zardoya, R. 2006. Molecular phylogenetics and evolutionary diversification of labyrinth fishes (Perciformes: Anabantoidei). Systematic Biology 55:374-397. https://doi.org/10.1080/10635150500541664

Sahu, S.; Das, B. K.; Mishra, B. K.; Pradhan, J.; Samal, S. K. and Sarangi, N. 2008. Effect of dietary Curcuma longa on enzymatic and immunological profiles of rohu, Labeo rohita (Ham.), infected with Aeromonas hydrophila. Aquaculture Research 39:1720-1730. https://doi.org/10.1111/j.1365-2109.2008.02048.x

Sambaiah, K.; Ratankumar, S.; Kamanna, V. S.; Satyanarayana, M. N. and Rao, M. V. L. 1982. Influence of turmeric and curcumin on growth, blood constituents and serum enzymes in rats. Journal of Food Science and Technology 19:187-190.

Srivastava, R. and Srimal, R. C. 1985. Modification of certain inflammation-induced biochemical changes by curcumin. Indian Journal of Medical Research 81:215-223.

Srivastava, R. M.; Singh, S.; Dubey, S. K.; Misra, K. and Khar, A. 2011. Immunomodulatory and therapeutic activity of curcumin. International Immunopharmacology 11:331-341. https://doi.org/10.1016/j.intimp.2010.08.014

Teo, L. H.; Chen, T. W. and Lee, B. H. 1989. Packaging of the guppy, Poecilia reticulata, for air transport in a closed system. Aquaculture 78:321-332. https://doi.org/10.1016/0044-8486(89)90109-9

Wei, S.; Xu, H.; Xia, D. and Zhao, R. 2010. Curcumin attenuates the effects of transport stress on serum cortisol concentration, hippocampal NO production, and BDNF expression in the pig. Domestic Animal Endocrinology 39:231-239. https://doi.org/10.1016/j.domaniend.2010.06.004

R. Bras. Zootec., 48:e20160282, 2019 
Wendelaar Bonga, S. E. 1997. The stress response of fish. Physiological Reviews 77:591-645. https://doi.org/10.1152/ physrev.1997.77.3.591

Xia, X.; Pan, Y.; Zhang, W. Y.; Cheng, G. and Kong, L. D. 2006. Ethanolic extracts from Curcuma longa attenuates behavioral, immune, and neuroendocrine alterations in a rat chronic mild stress model. Biological and Pharmaceutical Bulletin 29:938-944. https://doi.org/10.1248/bpb.29.938

Xia, X.; Cheng, G.; Pan, Y.; Xia Z. H. and Kong, L. D. 2007. Behavioral, neurochemical and neuroendocrine effects of the ethanolic extract from Curcuma longa L. in the mouse forced swimming test. Journal of Ethnopharmacology 110:356-363. https://doi.org/10.1016/j.jep.2006.09.042

Zeppenfeld, C. C.; Toni, C.; Becker, A. G.; Miron, D. S.; Parodi, T. V.; Heinzmann, B. M.; Barcellos, L. J. G.; Koakoski, G.; Rosa, J. G. S.; Loro, V. L.; Cunha, M. A. and Baldisserotto, B. 2014. Physiological and biochemical responses of silver catfish, Rhamdia quelen, after transport in water with essential oil of Aloysia triphylla (L'Herit) Britton. Aquaculture 418-419:101-107. https://doi.org/10.1016/j.aquaculture.2013.10.013

Zuanon, J. A. S.; Carneiro, A. P. S.; Nascimento, L. S.; Silva, D. A.; Pontes, M. D.; Kanashiro, M. Y. and Salaro, A. L. 2013. Protein requirement for Trichogaster lalius, blue variety. Revista Brasileira de Zootecnia 42:144-147. https://doi.org/10.1590/S1516-35982013000200010 